\title{
キャリア授業におけるクラス風土が生徒の動機づけに及ぼす影響 (2)
}

\author{
自己決定理論の観点からの検討 \\ ○大井はるえ ${ }^{1} \cdot$ 黑石憲洋 $^{2}$ \\ $\left({ }^{1}\right.$ 埼玉大学大学院教育学研究科 ${ }^{2}$ 日本教育大学院大学 $)$ \\ キーワード : 動機づけ, キャリア教育, 自己決定理論
}

Effects of Classroom Climates on Students' Academic and Career-related Motivation(2): From the Perspective of Self-determination Theory Harue $\mathrm{OOI}^{1}$ and Norihiro KUROISHI ${ }^{2}$

( ${ }^{1}$ Graduate School of education, Saitama Univ., ${ }^{2}$ Japan Professional School of Education)

Key Words: Motivation, Career Education, Self-Determination Theory

目 的

自己決定理論（Deci \& Ryan,1985）では、外発的動機づけ による行動は、自己調整の連続体の中で位置づけられ、3つ の基本的な欲求の充足を支援することで価值が内在化する とされる (Grolnick \& Ryan,1987)。

実証研究として、Grolnick \& Ryan（1987）は小学生の学習 について、統制の強い状況ではプレッシャーが強く、学習 効率が低下する一方、統制の弱 状況では興味や学習効率 が高まることを示した。

キャリア関連授業のクラス雾囲気と学業的・キャリア関 連の動機づけについて、大井・黒石(2012)では、自律性支援 と関連づけられる「意味や価值への方向づけ」は充実感・ 将来の展望や学習活動を促進し、構造と関連づけられる「枠 組みの強さ」は意欲や友人関係を促進し、無力感、職業忌 避傾向を減少させるといら結果が得られた。

本研究は、 3 年間のキャリアプログラムを推進しているあ る高等学校を取り上げ、縦断的研究の 2 年終了時における キャリア関連授業のクラス雰囲気が、学業的動機づけ・職 業忌避に及ぼす影響について検討した。

$$
\text { 方 法 }
$$

「学生生活、進路・職業について」学校におけるキャリア プログラムについてのアンケート」と題する質問紙調査を 実施した。

調査対象 キャリアプログラムを推進している工業高校の 第 2 学年全員 150 名を対象とし、学年中の退学者や調査当 日の久席者、その他重大な欠損值を含む対象者を除外し、 148 名を有効回答とした。

調査時期＼cjkstart各授業の終了する第 2 学年の終了時とした。 使用尺度 大井・黒石(2012)で作成したクラス雾井気を測定 する尺度を使用した。因子分析により「意味や価值への方 向づけ」および「枠組みの強さ」の 2 つ下位尺度から構 成される。

学業的動機づけの測定には、中学生版無気力感尺度（笠井 ら,1995）を使用した。また、キャリア関連の動機づけの測 定には、職業忌避的傾向尺度（古市ら,2007）を使用した。
結 果 キャリア関連授業のクラス雾囲気と学業的・キャリア関連 の動機づけの指標の相関係数を算出した (表参照)。

「意味や価值への方向づけ」は、すべての授業で「積極的 学習活動の欠如」と負に、ものづくりの授業で「充実感・ 将来の展望の欠如」と負に関連した。

「枠組みの強さ」は、すべての授業で「意欲減退・心身的 不全感」および「消極的友人関係」「無力感・あきらめ」と 負に、ものづくりの授業で「職業忌避傾向」と負に関連し た。また、体験の授業で「充実感・将来の展望の欠如」と 正に関連した。

\section{考 察}

大井・黒石(2012)の研究と同様、自律性支援と関連づけら れる「意味や価值への方向づけ」は学習活動やほぼ充実感・ 将来の展望を促進した。また構造と関連づけられる「枠組 みの強さ」は意欲や友人関係を促進し、無力感、職業忌避 傾向を減少させるといら結果が得られた。これらの効果は ほぼ弁別的であったことから、自律性支援と構造が相互に 異なる影響をもつものであることが示唆された。

また同様に、「意味や価值への方向づけ」は意欲を低め るとともに無力感を増加させ、「枠組みの強さ」は充実感 を減少させて、学習活動を消極的にすることが示された。

2年時にはインターンシップでの経験、修了時には生徒の 適性・進路希望にしたがって「機械加工」「オートメカニッ ク」「設備」「コンピューター」「デザイン・インテリア」に 専門科目が分かれ、職業決定は翌年に迫ってくる。現実に直 面していく中で、生徒はやりがい、充実感や意欲も感じ、次 第に無力感や職業忌避など言っておられず、友人と相談しな がら学習活動を進めざるを得ない状況になっていくのでは ないかと推測される。

Grolnick \& Ryan（1987）は小学生の学習について、統制の 強い状況ではプレッシャーが強くなると指摘したが、職業 決定を翌年に控えた高校生には、キャリアプログラム関連 授業の教員の与える「枠組み」が安心感を与え、無力感や 職業忌避を減少させて意欲を高める可能性が示唆された。

表 キャリア関連授業のクラス䨌囲気と 2 年次終了時の学業的・キャリア関連の動機づけの指標の相関係数

\begin{tabular}{|c|c|c|c|c|c|c|c|}
\hline \multirow[b]{2}{*}{ 授業 } & & \multicolumn{5}{|c|}{ 無気力 } & \multirow{2}{*}{ 職業忌避傾向 } \\
\hline & & 意欲减退 & 充実感の欠如 & 消極的友人関係 & $\begin{array}{l}\text { 無力感 } \\
\end{array}$ & 学習活動の欠如 & \\
\hline \multirow[t]{2}{*}{$\mathrm{CG}$} & 価值づけ & .094 & -.154 & .012 & .041 & $-.168^{*}$ & -.007 \\
\hline & 枠組み & $-.326 * *$ & .014 & $-.369 * *$ & $-.265 * *$ & .040 & -.141 \\
\hline \multirow{2}{*}{ ものづくり } & 価值づけ & .134 & $-.186^{*}$ & .023 & .116 & $-.306^{* *}$ & -.040 \\
\hline & 枠組み & $-.322 * *$ & .024 & $-.483 * *$ & $-.313 * *$ & .039 & $-.222 *$ \\
\hline \multirow[t]{2}{*}{ 体験 } & 価值づけ & .011 & -.078 & -.020 & .079 & $-.188 *$ & .052 \\
\hline & 枠組み & $-.275 * *$ & $.197 *$ & $-.374 * *$ & $-292 * *$ & .080 & -.099 \\
\hline
\end{tabular}

$* * \mathrm{P}<.01 * \mathrm{P}<.05$ 